\title{
TO DISCLOSE A LESS GENERIC PRONOUN: ADDRESSING THE NON-BINARY "THEY"
}

\author{
Izzatia Nabila ${ }^{1}$, Slamet Setiawan ${ }^{2}$, Widyastuti ${ }^{3}$ \\ 1English Department, Faculty of Language and Art, State University of Surabaya \\ Izzatianabila16020154084@mhs.unesa.ac.id \\ 2English Department, Faculty of Language and Art, State University of Surabaya \\ slametsetiawan@unesa.ac.id \\ 3English Department, Faculty of Language and Art, State University of Surabaya \\ widyas@unesa.ac.id
}

\begin{abstract}
Since the $13^{\text {th }}$ century singular they have been used freely to account for the lack of gender-fair pronouns in the English language. Singular they that is normally employed as a pronominal non-possessive indefinite singular pronoun, in contrast to an expression on he/she generic. This study aims to provide a linear timeline that accounts for the usage of singular they from the $13^{\text {th }}$ century to the present date through diachronic studies. This study offers an analysis of context with diachronic relevance. The study uses argumentative cross-examination methods, by combing previous findings conducted by researchers who had undertaken and attempted to write under a similar theme. The results of this study show periodical changes from $13^{\text {th }}$ century to the present, implying that sociocultural changes may be reflected in linguistic changes. The article postulates some that can be interpreted as lenient acceptance for the application of singular they. This study concludes despite the constant rejection singular they are a proper substitute for the gender-neutral pronoun in the English language due to two major advantages for singular they could afford neutrality and naturalness element in comparison to neologism.
\end{abstract}

Keywords: singular, pronoun, they, diachronic

Abstrak: Kata ganti they telah digunakan secara bebas untuk mengisi ketiadaannya kata ganti tanpa gender dalam bahasa Inggris. Kata ganti tunggal they yang biasanya digunakan sebagai kata ganti tunggal pronominal non-posesif tak tentu, layaknya ungkapan he/she generik. Penelitian ini bertujuan untuk memberikan garis waktu linier yang memperhitungkan penggunaan kata tunggal they dari abad ke-13 hingga saat ini. Menjelaskan melalui ruang lingkup studi Diachronic. Studi ini menawarkan analisis konteks dengan relevansi diakronis. Hasil penelitian studi menunjukkan perubahan berkala dari satu dekade ke dekade berikutnya, yang menyiratkan bahwa perubahan sosial budaya dapat tercermin dalam perubahan linguistik. Artikel ini mendalilkan beberapa implikasi metodologis yang dapat diartikan sebagai penerimaan yang lunak untuk penerapan kata ganti tunggal they. Lebih lanjut menegaskan meskipun penolakan konstan terhadap pengaplikasian they adalah pengganti yang tepat untuk karena dua keuntungan utama, yakni kata ganti tunggal they mampu memberikan unsur netralitas dan kealamian dibandingkan dengan neologisme/neopronoun.

Kata Kunci: tunggal, kata ganti, they, diakronik 


\section{INTRODUCTION}

Singular they have been used freely to account for the lack of gender-fair pronoun in the English language. Singular they that is normally employed as a pronominal non-possessive indefinite singular pronoun, in contrast to an expression on he/she generic. Singular they have factors in which restrain and limit some context while permitting broad implications use in other (Newman, 1998). Most notably is the use is acceptable in indefinite (each, every, any anyone, anybody, everyone, everybody, nobody, no one someone, somebody, and whoever). Along the same line it is almost natural to write 'I' for 1st point of view (POV) or in 3rd person objective signified by the use of 'she' especially generic 'he', and 'they' (Balhorn 2004). Otherwise, there are cases where no personal pronoun was used at all.

Singular 'they' that could infer and function as 'us' or 'we' to distance a personal bias in writing, can also be used in a singular format in reference to a specific individual (non-binary). These days, more people are writing the pronoun 'I' by substituting to 'they' for either cause.

This study focuses on the Diachronic linguistic aspect also known as the historical branch of linguistic that is devoted to the changes of language over time. Any language will have changes, be it in small forms and an inconsistent pattern, or be it the chief element, which challenges the overall structure. By studying, the changes within a period of time it enabled us to create a timeline regarding language shifts from semantic, structure even to the disappearance of language elements. In this present study, we scrutinize the lack of gender-neutral pronoun in English to the acceptance of singular they across $13^{\text {th }}$ to 21 st century.

It is not something new, for, singular 'they' have been unequivocally used by the canon of world's literature during the $13^{\text {th }}-18^{\text {th }}$ century including Chauffer, Shakespeare, Jane Austen, (Johnson 2004; Balhorn 2004) despite never been accepted formally (Baranowski 2002). Moreover, it owed partial of its prominent due to the backlash against feminism that arose back in the 1970s.

Linguists across many specific fields have a strong argument concerning singular 'they'; many proposed this to be grammatically unacceptable and used a political facet pressured as a seism in a specific era. Mackay (1980) who represented most of his peers in the $18^{\text {th }}-19^{\text {th }}$ agreed and acknowledged the lack of gender-neutral consensus might cause several problems was particularly stern in refusing singular 'they' as a preferable choice in the absence of natural gender pronoun in English language and following in his footsteps many avoided the use in formal writing setting.

It is argued English personal third-person pronouns are compelled to change to mirror the new ideology and social practices and common-gender pronouns would have arisen by the pressure imposed (Baron 1981). In the continuous pursuit of deciding a gender-fair or non-sexist to be prescribed above all, by professional associates (Stahlberg and Sczesny 2007) or by the general populace is thus emphasized. Especially, during the times when gender is no longer binary.

Although there are potential ambiguities by using singular 'they' and/or non-binary 'they', singular 'they' still encouraged to be used. In this present study by taking into account the diachronic linguistics approach, this study argues why 
potentially singular they will rise to prominence in favour of previous arguments raised across centuries pertaining to its use. This study owes a large proportion of its data to the novel, articles, journals, books that were written using the firstperson objective by using the pronoun they. This study tries to counteract by using several data, research, and argumentation raised to back the use of singular 'they' and briefly illustrate the place of non-binary 'they' in English language corpus. Moreover, this study discourages the use of the neopronoun in support of the use of the singular 'they'.

The English language we now know and use today was introduced into Great Britain about 1,500 years ago by invaders from the North Sea coasts of continental Europe (Millar \& Trask, 2007). As time progresses new words are coined and come into direct use, where certain words can have decline use or slowly disappeared for some words it works the opposite way as in evident in singular they.

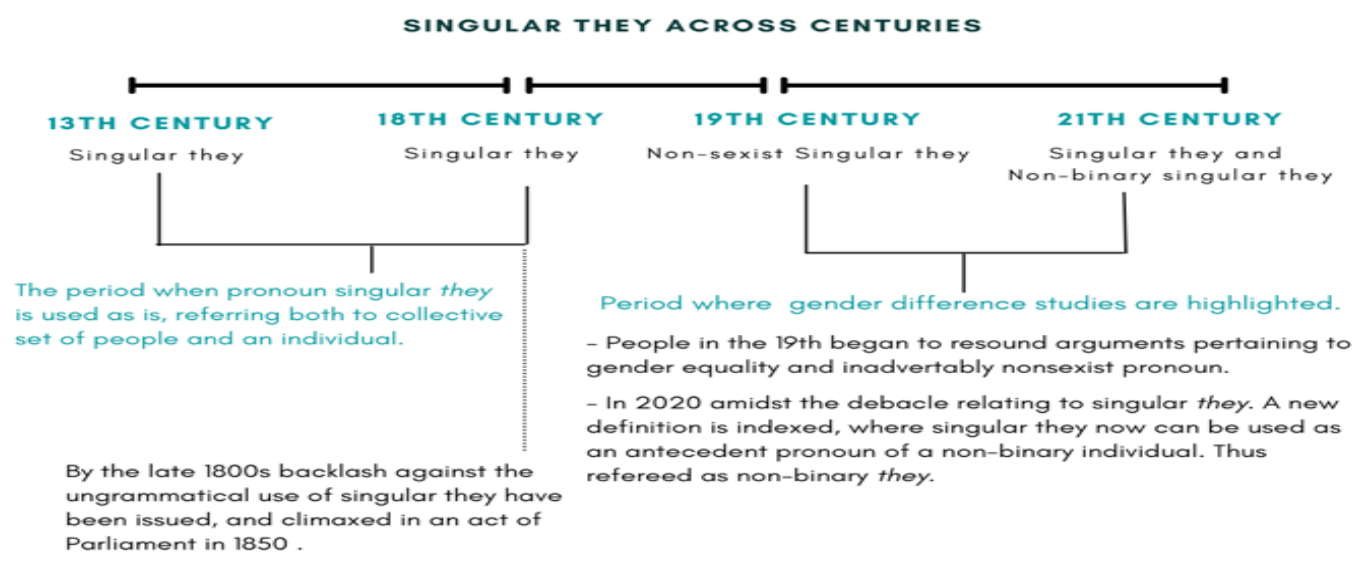

Figure 1: History of singular "they"

According to the Figure 1 above, singular they have had undergone several changes across centuries. In consideration to the temporal context of meaning in its usage is crucial to comprehend that the notion of time is a cultural formation (see the progression of singular they in the table above), where the culture in itself fused to the language is a reflection of what is going on with the people of that culture. This perspective is constructed through culture and not simply inevitably fused to a linear development of events or an objective clock-based time - both cultural constructs enshrined in modernity (Hyatt 2005) By studying the changes of the pronoun they had proven language is constantly evolving, and more robust in reflection to its users (Hopper 1988).

Research paralleled to the study of culture, society, history and language will be examined under the branch of Diachronic linguistics. The connection between modern English to its predecessor prototypes typically studied under this branch of study. Besides concepts of culture as our external forces have always been important in the study of the connection between language and society, not to mention the power and political stance in showing solidarity as collective beings (Arnold et al. 2000; Milani 2017; Palomares 2008; Bodine 1973)

According to Weiss and Wodak (2003), they proposed the DiscourseHistorical Approach to transcend the wholesome linguistic dimension and to 
comprise methodically the political, sociological historical and/or psychological dimensions in the body of study (Hyatt 2005).

The Wodak and Weiss approach pay heed into four categories:

1. Linguistic Analysis - the surface layer in which co-textual and language aspects, containing pragmatic strategies that could be evaluated.

2. Discourse Theory - the interdiscursive and intertextuality relationships from utterances, genres, texts and discourse are considered.

3. Middle-Range or Meso-Theories - is the extra-linguistic social and sociological factors.

4. Grand Theory - it covers the extensive historic and sociopolitical circumstances, which influence the expansive practices within the practices.

\section{METHODS}

The research was conducted by the progression of singular they across centuries, most of its data are journal, articles raised and complied pertaining to the use of the epicene pronoun, and singular they. There are some steps to take to analyze the data that had been obtained, such as reading the source of the data, collecting and classifying the finding data into different needs based on the theory, which is used before analyzing the data.

By merging several argumentations into one, and fuse the study through wide arrays of theory, this study tries to limit itself to the development of singular they and its development over a few centuries.

\section{FINDINGS AND DISCUSSION The Shift across Centuries}

\section{$13^{\text {th }}$ Century}

The $13^{\text {th }}$ Old English listed three personal subject pronouns), hēo (for feminine nominative), hē (for masculine nominative and hīe (plural nominative, could infer to any gender). Resulting from a period of forceful interaction with the Vikings and their language (Norse), Middle English had espoused the Old Norse plural masculine expressive peir for their plural pronoun, further known as they/thei ("Singular They | Druide," n.d.). Herein an example below taken from Wycliffe (1382)

A. Eche on in per craft ys wijs. ("Each one in their craft is wise.")

The subsequent centuries abundant samples of they/their/them with a singular antecedent, often one of an indeterminate individual (whoever, someone, somebody so forth) such as the text down below

B. If that [men] liste this folk [they] knowe may. - (Chaucer 1392)

C. And [a brat] to walken inne by daylight, [they] wolde hem selle and speden on this craft (Chaucer 1392) 
In-text B antecedent they referred to $\underline{\text { men, }}$ as was speculated before, however, in-text $C$ this suggested that antecedent they here which referred to a brat is used freely that it can be used either way (referring to people or a person).

\section{$18^{\text {th }}-$ Early $1^{\text {th }}$}

She, he language (Xia 2013; Prewitt-Freilino, Caswell, and Laakso 2012; Palomares 2008; Bodine 1973) popularized as a term to coin the difference between binary gender of female and male on how each binary gender employs different stylization in which dominated the academia world back in the 18-19th. Co-operative women vs competitive men in other words male dominance and female subordination; this theory is no longer appropriate nor relevant to address people in the presence of non-binary people as the gender has now expanded to 64 . This extension from the two sex to 64 genders rooted deeply upon social concords and constructs (Berendt 2014). Moreover, by using, a centred generic pronoun-resolution has proven that the usage inferred people to assume and associate certain keywords with gender-marked keywords within the generic pronoun she and he constrain, specifically; it suggests that hearers had predetermined idea of referents to pronouns before construing the rest of the sentence (Kehler 1997). Moreover suggesting that grammatical gender encourages gender-relevant dispensation of social information (Prewitt-Freilino, Caswell, and Laakso 2012). .Furthermore, in one particular study (Lauren 2000) titled Sex, Syntax and Semantic, the journal research questions ask the same question of gendering on regard to how a language openness on things that are not binding, say gendering, help to cognitively shape our perceptivity and exercise a person's tolerance capability

\section{Late $1^{\text {th }}$}

Prescriptive grammarians often argued by using singular 'they' in whichever format may threaten, obscure the coherence and time processing of the usage. Singular 'they' although an agreeable substitution for pronoun with non-referential antecedent has been less acceptable for pronoun with referential antecedents for it might introduce ambiguity and insert gender vagueness (Mackay 1980; Bjorkman 2017; Foertsch and Gernsbacher 2014).

Baron has noticed the lack of gender-fair unassuming pronoun is important, in his 1981 he made a list of comprehensive epicene words that had failed to comply. Baron delivered through empirical glossary of the common gender, epicene and bisexual pronoun which later be termed as neopronoun. Neopronoun was introduced to negate the undesirable impact of using generic he voiced by feminist and complied attractively by Blevins (2018). 
Common neopronouns, with the singular 'they' included for reference, and examples of how they are used

\begin{tabular}{|l|l|l|l|l|l|}
\hline & $\begin{array}{l}\text { Subject } \\
\text { Pronouns }\end{array}$ & $\begin{array}{l}\text { Object } \\
\text { Pronouns }\end{array}$ & $\begin{array}{l}\text { Possessive } \\
\text { Adjectives }\end{array}$ & $\begin{array}{l}\text { Possessive } \\
\text { Pronouns }\end{array}$ & $\begin{array}{l}\text { Reflexive } \\
\text { Pronouns }\end{array}$ \\
\hline They & They laughed & I called them & Their eyes gleam & That is theirs & They like themselves \\
\hline Ne & Ne laughed & I called nem & Nir eyes gleam & That is nirs & Ne likes nemself \\
\hline Ve & Ve laughed & I called ver & Vis eyes gleam & That is vis & Ve likes verself \\
\hline Spivak & Ey laughed & I called em & Eir eyes gleam & That is eirs & Ey likes emself \\
\hline Ze/Zie and Hir & Ze laughed & I called hir & Hir eyes gleam & That is hirs & Ze likes hirself \\
\hline Ze/Zie and Zir & Ze laughed & I called zir & Zir eyes gleam & That is zirs & Ze likes zirself \\
\hline Xe & Xe laughed & I called $x e m$ & Xyr eyes gleam & That is xyrs & Xe likes xemself \\
\hline
\end{tabular}

Figure 2: Common Neopronouns

Fig. 2 asserts that English has always tried to fill the gap in the lack of gender-neutral pronoun. The explosion of censure of the singular 'they' climaxed in an Act of Parliament in 1850 (Bodine 1973). Albeit the strong repercussion against the use of generic he that appeared to be sexist and inherently carried androcentric POV. And when generic he is formulated through verbal ovation, to written scriptures, women, children (Stahlberg and Sczesny 2007; Bodine 1973) and marginal people's rights can be easily ignored under the pretence of the male gaze. In support to Bodine;s stance Gastil and Newman discoveries supported her postulation. In alignment to feminist critics, Gastil and Newman findings asserted the presence of sex-indeterminate generic he linguistically carried a male bias (Newman 1998; Gastil 1990) in which evident in the 19th-century scriptures.

\section{The 21st Non-Binary "they"}

As briefly, raised, many reforms had been taken to bridge the gap of gender and pronoun namely in favour of singular they. Julie, in her 2014 study supports the contention that singular they are an acceptable substitution for gender-specific pronouns with nonreferential antecedents, however, it is less acceptable with referential antecedents, for which ideally there should be no ambiguity about gender. (Foertsch and Gernsbacher 2014).

\section{Sentence such as}

A. The customer left their (possessive form) phone inside the store.

B. John had left their phone inside the house.

Are not acceptable. Kehler (1998) argued the pronoun resolution preferences that result from an addressee's immediate tendency to interpret a pronoun motivate pursuing a centring-based approach (Kehler 1997). Meaning for the hearer/reader of the text, for text A, singular they is more likely acceptable due to its non-referential gender-specific antecedent. Thus, less acceptable for text B.

In the rise of leniency towards the marginalized people and gender values in society (Bradley 2020), to a wide-ranging description of how and why thematic role (embodying a person's identity) information stimuli referent accessibility (Arnold 2010). With more people are accepting the singular they and non-binary singular they. First popularized by the non-binary individual who refused to be identified by either she/he. These individuals proposed an entirely new 
definition for singular they, rather than what was raised by Julie or Kehler, this definition referred to a specific antecedent that is a non-binary individual. This suggests the 21st take on singular they, rewrite the function by embedding a new meaning, from descriptive use as in-text A to a performative use that signified a personal choice of pronoun or known as preferred gender pronoun (PGPs).

The sentence sampling below is one example of the use of non-binary singular they.

\author{
Sorry, what was the instruction again? \\ MAN: \\ Travis, before you can make the burger, it is important you \\ decide the type of box the burger must go in.
}

TRAVIS opens the box to reveal two identical burger boxes. They

continue to search other boxes for boxes. TRAVIS speaks this next

text through the boxes until they are hidden.

Figure 3: Example of singular they in sentences (Alabanza 2018)

Where the highlighted they in the text referred to a specific individual named Travis, whose gender remained obscured, and this tells us, that Travis is using the pronoun they as an inner-grouper identity, thus whoever read this body of text could tell Travis potentially is a non-binary individual. This sample can be further studied under the umbrella of LGBTQ+ Linguistics; in this body of research, we simply try to dismantle the difference of singular they format across centuries.

\title{
The Shift from Collective to Personal Self
}

In the emergent of preferred gender pronouns (PGPs) in more contemporary writing to academic research have been prevalent in its flexibility to use singular 'they' both in its epicene form or non-binary singular format, and this challenged the long-withheld ideal of a woman or man's language as was briefly mentioned. As well as asserting that potentially a neutral gender-fair pronoun would have arisen by themselves.

As a follow suit an official entry by Merriam Webster Online Dictionary (Johnson 2004) in 2019 indexed a new definition for the pronoun 'they', it acknowledges pronoun 'they' in its singular 'they' to refer to a singular entity for the non-binary people in linkage to the movement for queer recognition and rights (Berendt 2014).

In its 21st-century application singular, they suggest a performative view in which pronoun they embody as an inter-grouper identity are judged solely in terms of their productivity in a temporal context. What is important to note, from the change evident in the 21st take on it is not to be seen as a form of gender neutrality nor it is not an attempt to remove gender from people (OdrowazCoates 2015). Rather the 21st attempt tried to incorporate the extra gender 
variable thinning the society 64-gender variables into pronoun she, he and they (singular/non-binary).

It is arguable whether English language terms of incorporating gender neutrality will follow Finland's footstep that has been successfully introduced the use of a gender-neutral pronoun hän. Alternatively, the infamous hen, its Swedish equivalent of hän that was introduced into the Swedish language back in 2011. In acknowledgement of social-political stance of the gender non-conformist people, and indivertibly bridge he (he) and hon (she), (Odrowaz-Coates 2015) In comparison, neologism in English (Blevins 2018) had posed to be excessive and troublesome for many of English speakers (Baron 1981; Newman 1998) had failed terribly in its execution.

\section{CONCLUSION}

This study concludes two major advantages for singular they and nonbinary singular they, both afford neutrality and naturalness aspect, one of being pronominal (each, every, any anyone, anybody, everyone, everybody, nobody, no one someone, somebody, and whoever) and performative pronoun (referring to specific antecedent re non-binary individual).

Since neologism had failed terribly in its execution in the English language, it is doubtful that English will follow Finland and Sweden footstep by introducing applicable gender-neutral pronoun. Albeit being a gender-neutral language it has proven that English had struggled to cope with the lack of gender-fair pronoun and have the tendency to be gender exclusive even if the context may be gender inclusive.

Further studies can be conducted on non-binary singular they, where much of its application account on the LGBTQ+ community, it is also foreseeable for the future due to the rise of LGBTQ+ literature that was born, sexist translation research can be conducted concerning non-binary they, especially hypnotized to affect the gendered language the most.

\section{REFERENCES}

Alabanza, Travis. 2018. Burgerz. London: Oberon Books.

Arnold, Jennifer E. 2010. "The Effect of Thematic Roles on Pronoun Use and Frequency of Reference Continuation," no. December 2014: 37-41. https://doi.org/10.1207/S15326950DP3102.

Arnold, Jennifer E, Janet G Eisenband, Sarah Brown-schmidt, and John C Trueswell. 2000. "The Rapid Use of Gender Information: Evidence of the Time Course of Pronoun Resolution from Eyetracking" 76: 13-26.

Balhorn, Mark. 2004. "The Rise of Epicene They." Journal of English Linguistics 32 (2): 79-104. https://doi.org/10.1177/0075424204265824.

Baranowski, Maciej. 2002. "Current Usage of the Epicene Pronoun in Written English," no. 1975: 378-97.

Baron, Dennis E. 1981. “THE EPICENE PRONOUN : THE WORD THAT FAILED” 56 (2): 83-97.

Berendt, Elise. 2014. "Gender-Neutral Pronouns: Inclusive , Subversive , Progressive."

Bjorkman, Bronwyn M. 2017. "Singular They and the Syntactic Representation of 
Gender in English." Glossa: A Journal of General Linguistics 2 (1): 80. https://doi.org/10.5334/gigl.374.

Blevins, K. R. 2018. "Neopronouns Explained."

Bodine, Ann. 1973. "Androcentrism in Prescriptive Grammar: Singular' They', Sex-Indefinite ' He', and ' He or She '," no. April 1973: 129-46.

Bradley, Evan D. 2020. "The Influence of Linguistic and Social Attitudes on Grammaticality Judgments of Singular ' They .'" Language and Communication 78: 101272. https://doi.org/10.1016/j.langsci.2020.101272.

Chaucer, Geoffrey. $1392 . \quad$ The Canterbury Tales. https://doi.org/10.4324/9780429341779-5.

Foertsch, Julie, and Morton Ann Gernsbacher. 2014. "In Search of Gender Neutrality: Is Singular 'They' a Cognitively Efficient Substitute for Generic 'He'?" 8 (2): 106-11.

Gastil, John. 1990. "Generic Pronouns and Sexist Language: The Oxymoronic Character of Masculine Generics." Sex Roles 23 (11-12): 629-43. https://doi.org/10.1007/BF00289252.

Hopper, Paul J. 1988. "Emergent Grammar and the A Priori Grammar Postulate." Linguistics in Context: Connecting Observation and Understanding, no. November: 117-34.

Hyatt, David. 2005. "Time for a Change: A Critical Discoursal Analysis of Synchronic Context with Diachronic Relevance." Discourse and Society 16 (4): 515-34. https://doi.org/10.1177/0957926505053054.

Johnson, Shawn. 2004. "Exploring the Use of the 'They' Pronouns Singularly in English" XXIX (1): 1-5.

Kehler, Andrew. 1997. "Current Theories of Centering for Pronoun Interpretation: A Critical Evaluation." Computational Linguistics 23 (3): 46775.

Lauren, A. 2000. "Proceedings of the Annual Meeting of the Cognitive Science."

Mackay, Donald G. 1980. "On the Goals, Principles, and Procedures for Prescriptive Grammar: Singular They - Linguistics and Language Behavior Abstracts (LLBA) - ProQuest." Language in Society 9 (3): 349-67.

Milani, Tommaso M. 2017. "Language and Sexuality."

Newman, Michael. 1998. "What Can Pronouns Tell Us? A Case Study of English Epicenes." Studies in Language 22 (2): 353-89. https://doi.org/10.1075/sl.22.2.04new.

Odrowaz-Coates, Anna. 2015. "Is Gender Neutrality a Post-Human Phenomenon? The Concept of 'gender Neutral' in Sweedish Education." Journal of Gender and Power 3 (1).

Palomares, Nicholas A. 2008. "Explaining Gender-Based Language Use: Effects of Gender Identity Salience on References to Emotion and Tentative Language in Intra- and Intergroup Contexts." Human Communication Research 34 (2): 263-86. https://doi.org/10.1111/j.1468-2958.2008.00321.x.

Prewitt-Freilino, Jennifer L., T. Andrew Caswell, and Emmi K. Laakso. 2012. "The Gendering of Language: A Comparison of Gender Equality in Countries with Gendered, Natural Gender, and Genderless Languages." Sex Roles 66 (3-4): 268-81. https://doi.org/10.1007/s11199-011-0083-5. 


\section{Lakon: Jurnal Kajian Sastra dan Budaya}

Volume 10. No. 2, November 2021

"Singular They | Druide." n.d. LANGUAGE MATTERS.

Stahlberg, Dagmar, and Sabine Sczesny. 2007. "Representation of the Sexes in Language," no. January 2007.

Wodak, Ruth, and Gilbert Weiss. 2003. "Critical Discourse Analysis: Theory and Interdisciplinarity." 2003.

Wycliffe. 1382. “John Wycliffe Bible 1382." Textus Receptus Bibles. 1382. http://textusreceptusbibles.com/Wycliffe.

Xia, Xiufang. 2013. "Gender Differences in Using Language." Theory and Practice in Language Studies. https://doi.org/10.4304/tpls.3.8.1485-1489. 